\title{
OPTIMALISASI PROSES PEMURNIAN SILIKON TINGKAT METALURGI MENGGUNAKAN CAMPURAN LARUTAN ASAM HCI DAN HF
}

\section{Optimalization of Metallurgical Grade Silicon Refining Process Using Mixture of Acids $\mathrm{HCl}$ and $\mathrm{HF}$}

\author{
BINTANG ADJIANTORO, M. YUNAN HASBI, EFENDI MABRURI, SIGIT D. YUDANTO, \\ NURHAYATI I. CIPTASARI, dan SEPTIAN A. CHANDRA
}

Pusat Penelitian Metalurgi dan Material - LIPI

Kawasan PUSPIPTEK Gedung 470, Muncul, Setu, Tangerang Selatan, Banten 15314

Telp. (021) 7560911

e-mail: bintangadjiantoro@yahoo.co.id

\begin{abstract}
ABSTRAK
Telah dilakukan percobaan pemurnian Metallurgical Grade Silicon (MG-Si) atau silikon tingkat metalurgi melalui proses pelindian. Proses pelindian menggunakan campuran larutan asam pada konsentrasi 2,45 mol/L $\mathrm{HCl}+1,2 \mathrm{~mol} / \mathrm{L} \mathrm{HF}$ yang dilakukan dengan memvariasikan waktu pelindian pada suhu $60^{\circ} \mathrm{C}$ dengan kecepatan putar $300 \mathrm{rpm}$. Hasil percobaan menunjukkan bahwa proses pelindian MG-Si dengan menggunakan campuran larutan asam pada konsentrasi $2,45 \mathrm{M} \mathrm{HCl}+1,2 \mathrm{M} \mathrm{HF}$ dapat menurunkan unsur pengotor yang terkandung di dalam MG-Si dan meningkatkan kemurnian seiring peningkatan waktu pelindian. Pada proses pelindian 12 jam, efisiensi ekstraksi unsur pengotor Al dan Fe mencapai 99,99\%, sedangkan untuk unsur Ti mencapai 99,96\%. Persentase efektivitas dari larutan pelindian selama 12 jam mencapai $99,96 \%$. Pencapaian tersebut berpeluang untuk ditingkatkan dengan memvariasikan konsentrasi maupun waktu pelindian sehingga diperoleh nilai optimal.
\end{abstract}

Kata kunci: silikon tingkat metalurgi, pelindian, efisiensi ekstraksi, efektivitas larutan.

\begin{abstract}
The purification process of Metallurgical Grade Silicon (MG-Si) using acid leaching method at a concentration of $2.45 \mathrm{~mol} / \mathrm{L} \mathrm{HCl}$ and $1.2 \mathrm{~mol} / \mathrm{L} \mathrm{HF}$ was performed by varying the leaching time at a temperature of $60^{\circ} \mathrm{C}$ with stirring speed of $300 \mathrm{rpm}$. The results showed that the MG-Si leaching process by mixing acid solution at a concentration of $2.45 \mathrm{~mol} / \mathrm{L} \mathrm{HCl}+1.2 \mathrm{~mol} / \mathrm{L} \mathrm{HF}$ was able to reduce elemental impurities in the MG-Si and improved its purity in line with leaching duration. With 12 hours of leaching time, the efficiency of Al and Fe extraction reached $99.99 \%$, while for Ti reached 99.96\%. The effectivity of the leaching process for 12 hours of leaching time reached $99.96 \%$. The achievement of this research can be improved further by varying the concentration of leaching agent and leaching duration to obtain more optimum results.
\end{abstract}

Keywords: metallurgical grade silicon, leaching, efficiency of extraction, effectivity of solution.

\section{PENDAHULUAN}

Pembangkit energi berbasis photovoltaic (PV) berkembang pesat sejak awal abad ke-21 (Ma dkk., 2009; Takiguchi, 2011; Yoshikawa dan Morita, 2012; Zhang $d k k_{.}$, 2013). Hal ini dikarenakan energi berbasis photovoltaic lebih bersih dan dapat diperbaharui (Yoshikawa dan
Morita, 2012; Zhang $d k k .$, 2013). Seiring dengan perkembangan PV, kebutuhan akan silikon tingkat surya (Solar Grade Silicon atau SoG-Si) sebagai bahan baku pembuatan sel surya (solar cell) semakin besar (Zhao $d k k$., 2011; Cai $d k k ., 2012$; Yoshikawa dan Morita, 2012; Hu dkk., 2013; Zhang $d k k ., 2013$; Tan $d k k ., 2014)$. Menurut Sarti dan Einhaus (2002) 
(diambil dari data Paul D. Maycock, 1989) dan Compaan (2006), kebutuhan bahan baku industri PV meningkat cukup pesat dengan laju pertumbuhan mencapai $30 \%$ pertahun. Gambar 1 menunjukkan pertumbuhan industri PV dan produksi silikon dan wafer berdasarkan data Asosiasi Industri PV Eropa (EIPA). Data tersebut menunjukkan kecenderungan semakin meningkatnya kebutuhan energi PV yang tersebar di berbagai negara dan China merupakan salah satu negara Asia yang memiliki pertumbuhan cukup tinggi dalam penggunaan teknologi PV.

SoG-Si sebagai bahan baku pembuatan sel surya diperoleh melalui proses pemurnian silikon tingkat metalurgi (Metallurgical Grade Silicon atau MG-Si) untuk menghilangkan unsur-unsur logam pengotornya. Beberapa metode yang digunakan untuk pemurnian MGSi antara lain: metode Siemens (Takiguchi, 2011; Silicor Materials, 2015), pelindian (Ma $d k$., 2009; Sun $d k$., 2013; Visnovec $d k$., 2013), dan directional solidification (Martorano $d k k ., 2011$; Tan $d k k ., 2014)$. Metode Siemens merupakan metode pemurnian yang sudah ada sejak tahun 1960-an (Takiguchi, 2011; Silicor Materials, 2015). Pada dasarnya, metode Siemens adalah metode pemurnian dengan cara mereaksikan MG-Si dengan asam klorida $(\mathrm{HCl})$ untuk memperoleh trichlorosilane $\left(\mathrm{SiHCl}_{3}\right)$ melalui proses distilasi $(\mathrm{Si}+3 \mathrm{HCl} \rightarrow$ $\mathrm{SiHCl}_{3}+\mathrm{H}_{2}$ ). Hasil destilasi ini kemudian diuraikan kembali menjadi Si menggunakan hidrogen $\left(\mathrm{SiHCl}_{3}+\mathrm{H}_{2} \rightarrow \mathrm{Si}+3 \mathrm{HCl}\right)$ (Takiguchi, 2011; Silicor Materials, 2015). Metode pelindian MG-Si adalah melakukan perlakuan terhadap serbuk MG-Si dengan $\mathrm{H}_{2} \mathrm{SO}_{4}$, aqua regia, $\mathrm{HF}$, dan asam-asam lainnya. Sedangkan metode directional solidification adalah metode pemurnian yang didasarkan pada sifat fisik (koefisien segregasi) unsur-unsur pengotor (Martorano $d k k ., 2011$; Tan $d k k_{\text {., }}$ 2014).
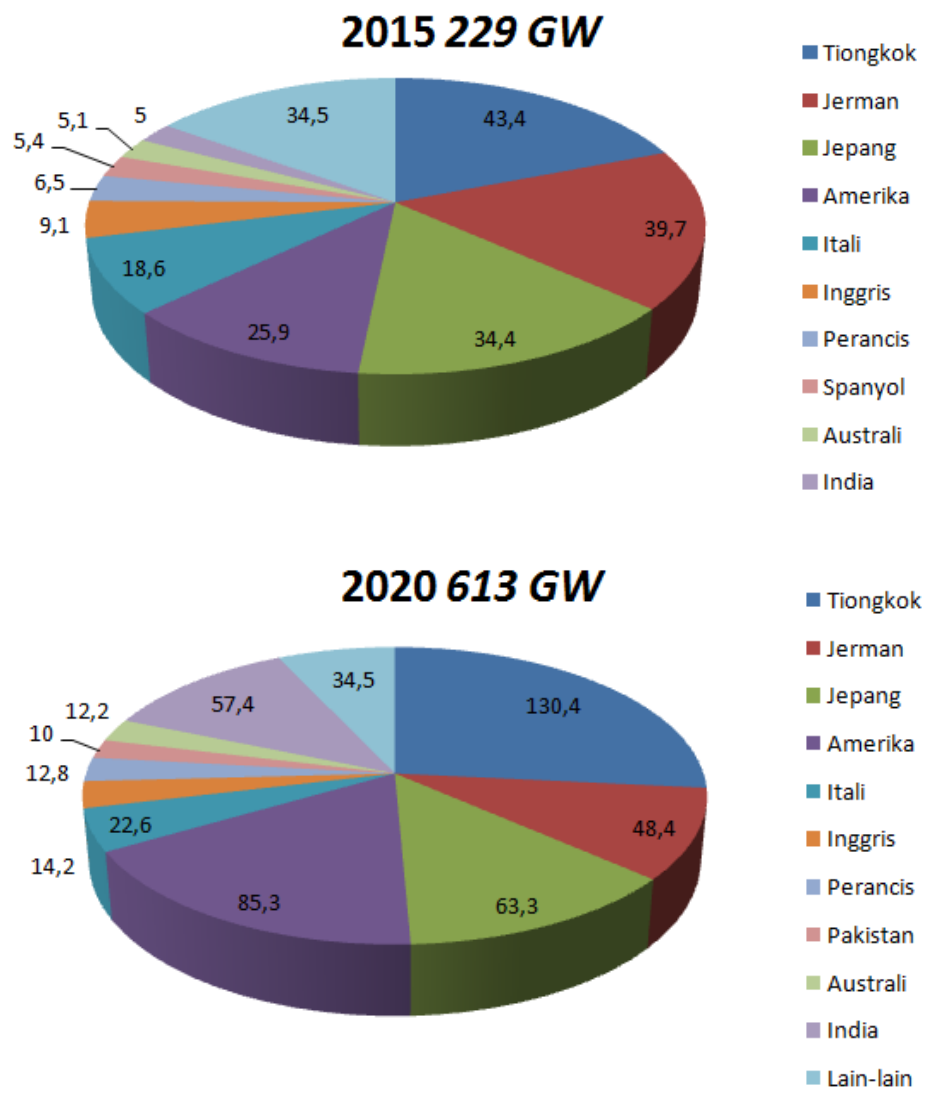

Gambar 1. Kapasitas total PV terpasang di 10 negara besar dunia tahun 2015 dan perkiraan di tahun 2020 (Powerweb, 2016) 
Pemurnian MG-Si dengan metode pelindian merupakan salah satu metode pemurnian yang umum dipakai. Menurut Ma dkk. (2009), pemurnian dengan metode pelindian dapat menghasilkan kemurnian lebih dari 99,9\% dari bahan baku MG-Si dengan kemurnian 98\%. Selain itu, keuntungan dari metode pelindian adalah penggunaan peralatan yang sederhana, biaya murah dan kuantitas hasil yang besar.

Tujuan penelitian ini adalah untuk mengetahui komposisi variasi yang sesuai antara konsentrasi larutan asam dan durasi proses pelindian untuk memperoleh silikon dengan kemurnian tinggi.

\section{METODE}

Percobaan diawali dengan menghancurkan MG-Si yang berbentuk bongkahan (hasil proses reduksi $\mathrm{SiO}_{2}$ ) menjadi serbuk lalu diayak hingga memperoleh MG-Si dengan ukuran < $50 \mu \mathrm{m}$. Serbuk hasil pengayakan kemudian dilakukan proses pemisahan unsur Fe menggunakan wet magnetic separator. Pemisahan menggunakan magnetic separator menghasilkan tailing (non Fe) dan konsentrat (Fe). Hasil yang berupa tailing diendapkan, dan dikeringkan. Endapan dianalisis menggunakan Atomic Absorption Spectroscopy (AAS).

Langkah berikutnya adalah melakukan pelindian 250 gram konsentrat MG-Si menggunakan larutan campuran 2,45 mol/L $\mathrm{HCl}$ dan 1,2 mol/L HF di dalam container polipropilen dan dilakukan pengadukan mekanik (mechanical stirring) dengan kecepatan $300 \mathrm{rpm}$ pada suhu $60^{\circ} \mathrm{C}$ (Ma $d k k$., 2009) dengan variasi waktu 6, 8, 10, dan 12 jam. Masing-masing hasil pelindian disaring. Padatan hasil penyaringan dicuci dengan air suling dan dikeringkan.

Padatan hasil pelindian ini dianalisis menggunakan Atomic Absorption Spectroscopy (AAS) untuk mengetahui konsentrasi unsurunsur yang terkandung dalam percontoh. Karakterisasi metalografi dilakukan untuk mengetahui struktur mikro permukaan percontoh dengan perbesaran 200 dan 500x. Sedangkan untuk mendukung hasil uji metalografi dilakukan pengamatan struktur mikro menggunakan Scanning Electron
Microscope (SEM). Diagram alir percobaan dapat dilihat pada Gambar 2.

\section{HASIL DAN PEMBAHASAN}

\section{Analisis Komposisi Kimia}

Karakterisasi awal percontoh menggunakan AAS untuk mengetahui konsentrasi unsur pengotor dalam MG-Si sebelum proses pelindian. Dari hasil karakterisasi didapatkan hasil seperti ditunjukkan pada Tabel 1 .

Tabel 1. Konsentrasi unsur logam pengotor dalam MG-Si

\begin{tabular}{cccccc}
\hline Unsur & $\mathrm{Al}$ & $\mathrm{Fe}$ & $\mathrm{Ca}$ & $\mathrm{Ti}$ & Epengotor \\
\hline$\%$ Berat & 0,5 & 0,5 & 0,3 & 0,02 & 1,32
\end{tabular}

Unsur-unsur pengotor yang utama terdapat dalam percontoh MG-Si antara lain $\mathrm{Al}, \mathrm{Fe}, \mathrm{Ca}$, dan $\mathrm{Ti}$ dengan jumlah konsentrasinya mencapai 1,32 \%, sehingga konsentrasi unsur Si sekitar 98,68\%. Setelah proses pelindian, padatan dikarakterisasi menggunakan AAS seperti ditunjukkan pada Tabel 2.

Tabel 2. Analisis konsentrasi unsur pengotor setelah proses pelindian menggunakan AAS

\begin{tabular}{cccc}
\hline Waktu & \multicolumn{3}{c}{ Kandungan Unsur (ppm) } \\
\cline { 2 - 4 } Pelindian & $\mathrm{Al}$ & $\mathrm{Ti}$ & $\mathrm{Fe}$ \\
\hline 6 Jam & $<0,01$ & 7.105 & 3.130 \\
8 Jam & $<0,01$ & 5.667 & 1.730 \\
10 Jam & $<0,01$ & 4.454 & 1.570 \\
12 Jam & $<0,01$ & 4.029 & 0.001 \\
\hline
\end{tabular}

Analisis kimia terhadap percontoh hasil pelindian dengan variasi waktu yang ditunjukkan pada Tabel 2 memperlihatkan bahwa semakin bertambahnya waktu pelindian, kandungan unsur pengotor yang ada di dalam percontoh MG-Si semakin berkurang dengan kata lain tingkat kemurnian silikon semakin meningkat. Sebagaimana penelitian yang dilakukan oleh Jian $d k k$. (2009) menyatakan bahwa kuantitas pengotor berkurang seiring penambahan waktu pelindian. Untuk unsur Ca sendiri dianggap terlarut sempurna dalam larutan asam karena merupakan unsur golongan $2 \mathrm{~A}$. 
Untuk mengetahui efisiensi ekstraksi dari campuran larutan asam dengan konsentrasi 2,45 $\mathrm{mol} / \mathrm{L} \mathrm{HCl}+1,2 \mathrm{~mol} / \mathrm{L} \mathrm{HF}$, digunakan perhitungan seperti pada persamaan 1 (Tavengwa, Cukrowska dan Chimuka, 2015).

$$
\left[\text { Efisiensi ekstraksi }=\left\{\left(\frac{E p-E q}{E p}\right) \times 100 \%\right\}\right]
$$

Ep $=$ konsentrasi tiap unsur pengotor sebelum pelindian (dalam ppm)

$\mathrm{Eq}=$ konsentrasi tiap unsur pengotor setelah pelindian (dalam ppm)
Hasil perhitungan terhadap efisiensi ekstraksi unsur pengotor dengan campuran larutan asam dengan konsentrasi 2,45 mol/L HCl + 1,2 mol/L $\mathrm{HF}$, pada waktu pelindian 6 sampai dengan 12 jam ditunjukkan pada Gambar 3. Terlihat bahwa nilai efisiensi ekstraksi untuk pelepasan unsur pengotor $\mathrm{Al}$, Fe dan $\mathrm{Ti}$ cenderung meningkat dengan bertambahnya waktu pelindian. Persentasi efisiensi ekstraksi pelepasan unsur pengotor Al dan Fe mencapai 99,99\%, sedangkan untuk pelepasan unsur Ti mencapai 99,96\% selama proses pelindian 12 jam.

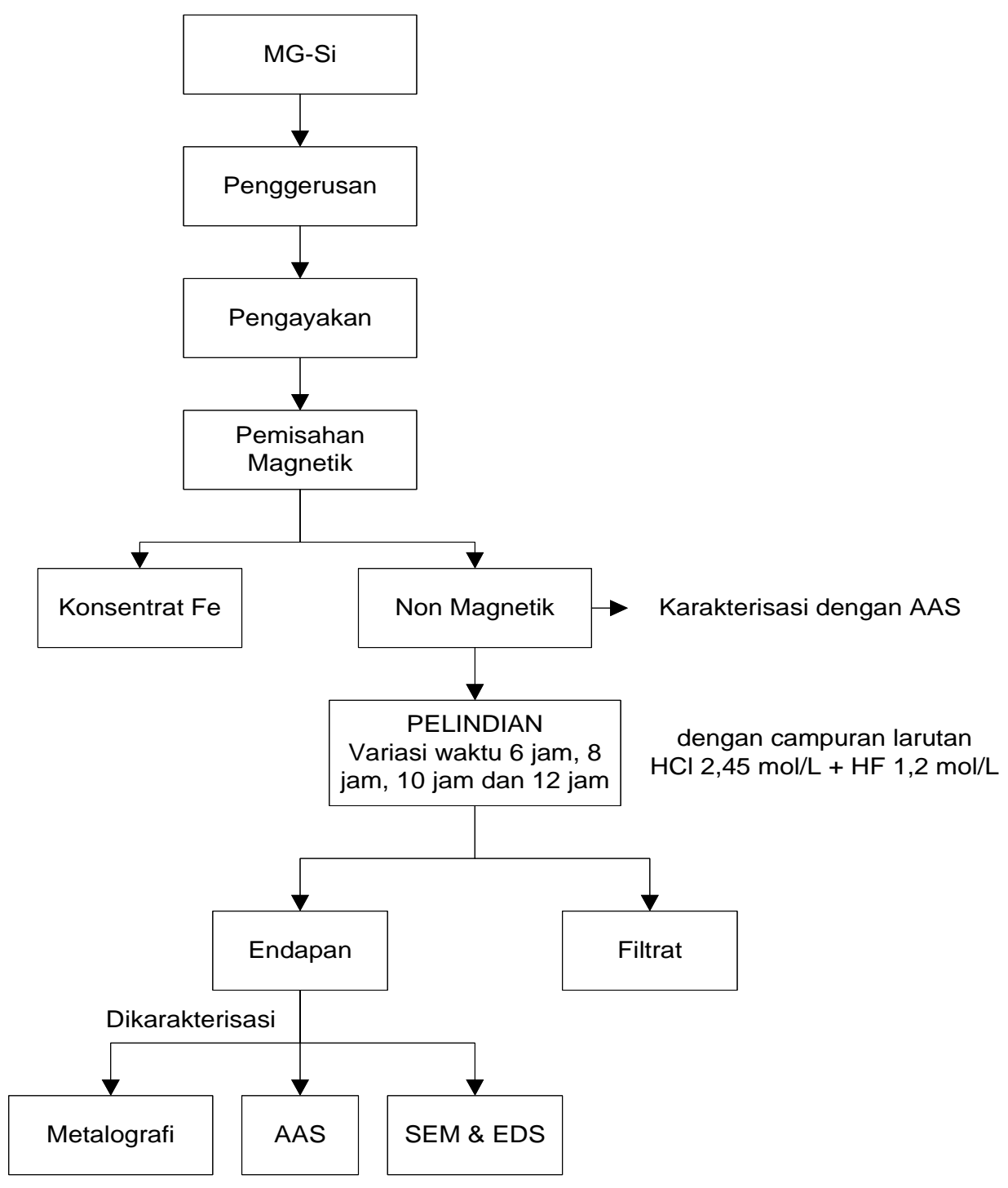

Gambar 2. Diagram alir percobaan pelindian MG-Si dengan menggunakan campuran $\mathrm{HCl} 2,45 \mathrm{~mol} / \mathrm{L}$ dan $\mathrm{HF} 1,2 \mathrm{~mol} / \mathrm{L}$ 
Sedangkan untuk mengetahui efektivitas larutan, digunakan perhitungan seperti pada persamaan 2 .

Efektivitas larutan $=\left\{\left(\frac{\sum \mathrm{n}-\sum \mathrm{p}}{\sum \mathrm{n}}\right) \times 100 \%\right\}$

$\Sigma \mathrm{n}=$ jumlah total konsentrasi unsur pengotor sebelum pelindian (dalam ppm)

$\Sigma p=$ jumlah total konsentrasi unsur pengotor setelah pelindian (dalam ppm)

Dari hasil perhitungan terhadap efektivitas campuran larutan asam dengan konsentrasi $2,45 \mathrm{~mol} / \mathrm{L} \mathrm{HCl}+1,2 \mathrm{~mol} / \mathrm{L} \mathrm{HF}$, pada berbagai waktu pelindian, ditunjukkan pada
Gambar 4. Terlihat bahwa efektivitas larutan pelindian (leaching effectiveness) dengan menggunakan campuran larutan asam dengan konsentrasi $2,45 \mathrm{~mol} / \mathrm{L} \mathrm{HCl}+1,2 \mathrm{~mol} / \mathrm{L} \mathrm{HF}$, cenderung meningkat dengan bertambahnya waktu pelindian. Hal ini membuktikan bahwa konsentrasi campuran larutan asam 2,45 $\mathrm{mol} / \mathrm{L} \mathrm{HCl}+1,2 \mathrm{~mol} / \mathrm{L} \mathrm{HF}$, membutuhkan waktu reaksi yang optimal.

Persentasi efektivitas larutan pelindian terhadap unsur pengotor $\mathrm{Al}$, Ti dan Fe dengan campuran larutan asam pada konsentrasi 2,45 $\mathrm{mol} / \mathrm{L} \mathrm{HCl}+1,2 \mathrm{~mol} / \mathrm{L} \mathrm{HF}$, selama waktu pelindian 12 jam mencapai 99,97\%.

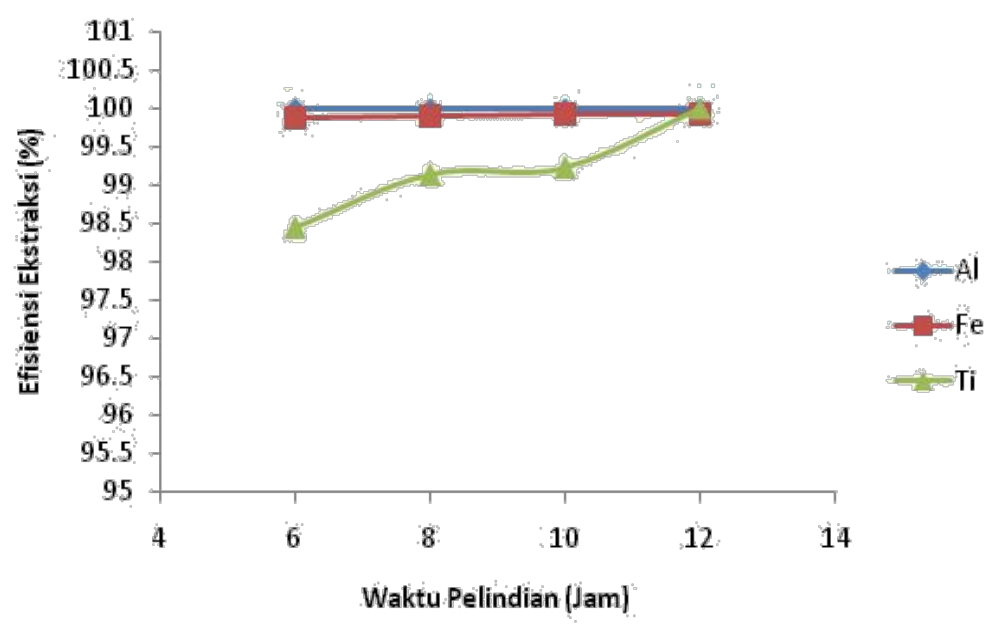

Gambar 3. Pengaruh waktu pelindian terhadap efisiensi ekstraksi unsur pengotor

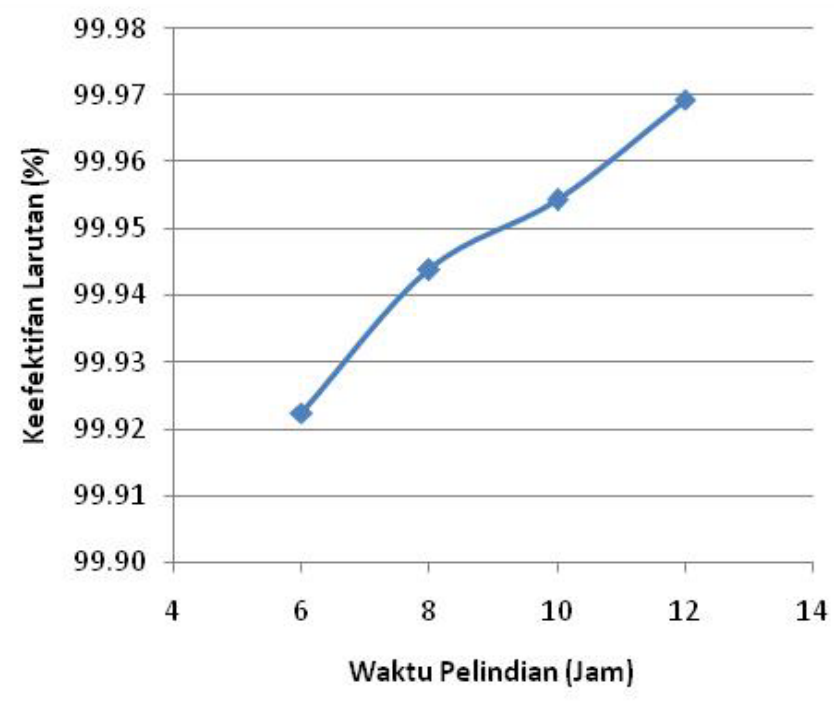

Gambar 4. Pengaruh waktu pelindian terhadap efektivitas larutan 


\section{Analisis Metalografi}

Karakterisasi metalografi bertujuan untuk mengetahui struktur mikro pada partikel Si. Hasil uji metalografi percontoh hasil pelindian ditunjukkan pada Gambar 5 s/d 8. Dari gambar struktur mikro tersebut terlihat bahwa pada waktu pelindian 6, 8, dan 10 jam, partikel Si masih mengandung unsur pengotor yang terdapat pada batas butir kristal Si. Sedangkan pada waktu pelindian 12 jam, partikel Si relatif bersih dari unsur pengotor khususnya pada butir kristal Si.
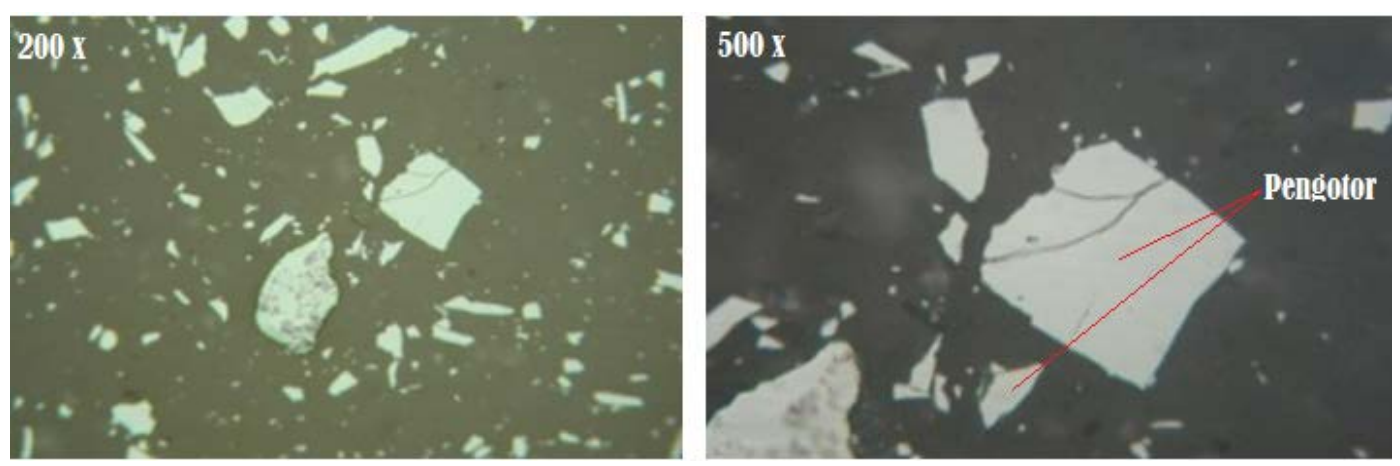

Gambar 5. Partikel silikon setelah proses pelindian selama 6 jam.

(a) perbesaran 200x dan (b) perbesaran 500x
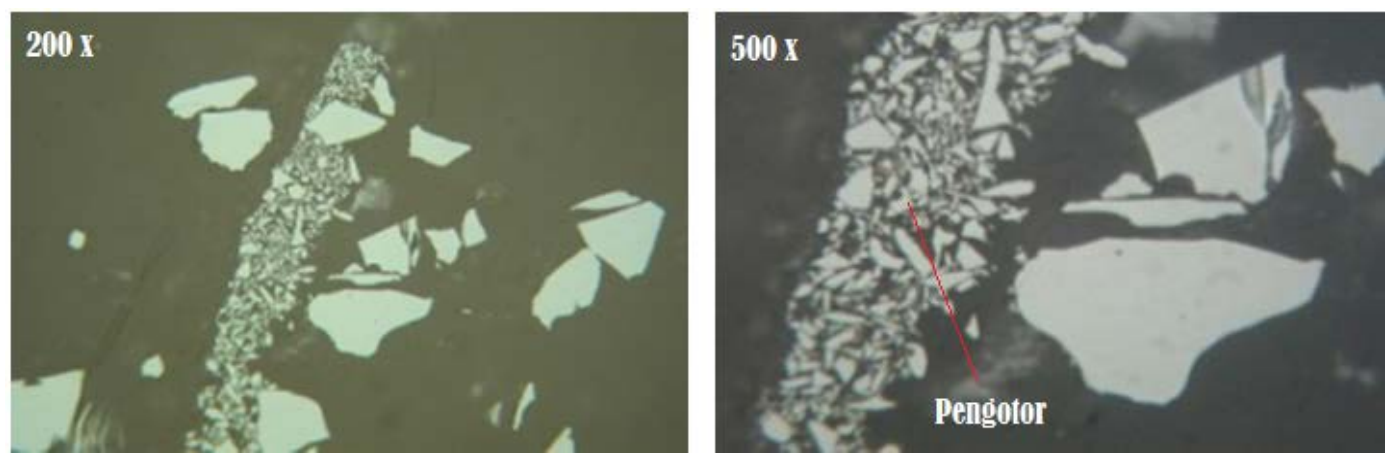

Gambar 6. Partikel silikon setelah proses pelindian selama 8 jam.

(a) perbesaran 200x dan (b) perbesaran 500x
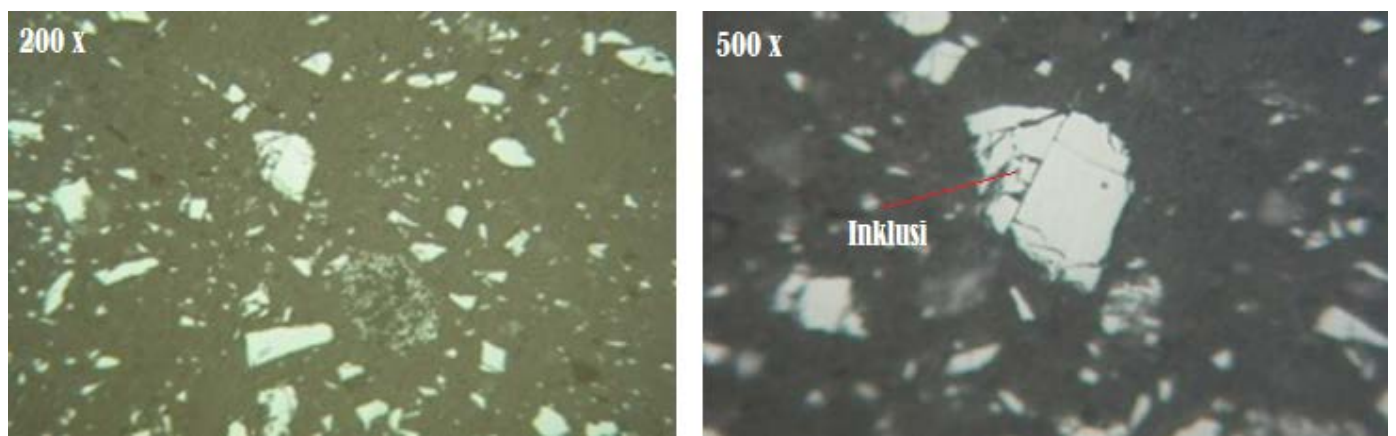

Gambar 7. Partikel silikon setelah proses pelindian selama 10 jam.

(a) perbesaran 200x dan (b) perbesaran 500x 

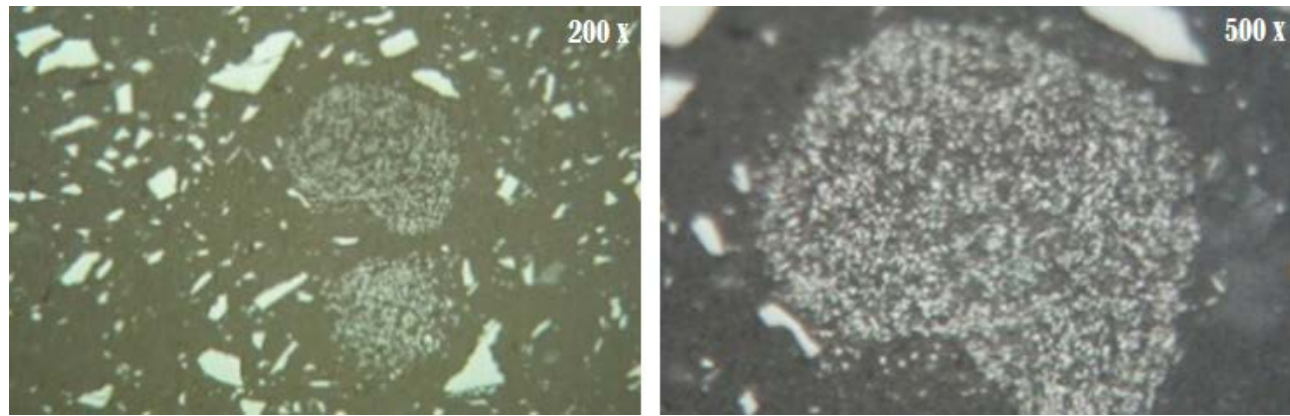

Gambar 8. Partikel silikon setelah proses pelindian selama 12 jam.

(a) perbesaran 200x dan (b) perbesaran 500x

\section{Analisis SEM/EDS}

Pengamatan menggunakan SEM bertujuan untuk mengetahui struktur mikro permukaan percontoh hasil pelindian, sedangkan EDS berguna untuk mengetahui unsur-unsur yang pada percontoh hasil pelindian secara semikuantitatif. Citra mikroskop elektron percontoh sebelum dilakukan pelindian dan hasil pelindian ditunjukkan pada Gambar 9 s/d 12 .

Dari keempat gambar struktur mikro tersebut terlihat bahwa struktur mikro percontoh hasil pelindian mempunyai morfologi yang seragam. Selanjutnya dapat dilihat bahwa permukaan partikel silikon pada masing-masing waktu tahan menunjukkan kondisi yang bersih dibandingkan dengan percontoh sebelum pelindian. Kemudian jika percontoh ditinjau menggunakan perbesaran 5000x maka percontoh hasil pelindian menunjukkan permukaan yang lebih bersih seiring peningkatan waktu tahan pelindian.

Sedangkan berdasarkan analisis EDS pada luas permukaan tertentu terlihat bahwa proses pelindian dengan variasi waktu menghasilkan unsur tunggal, yaitu silikon (Si) yang ditunjukkan pada Gambar 13 (b,c dan d).
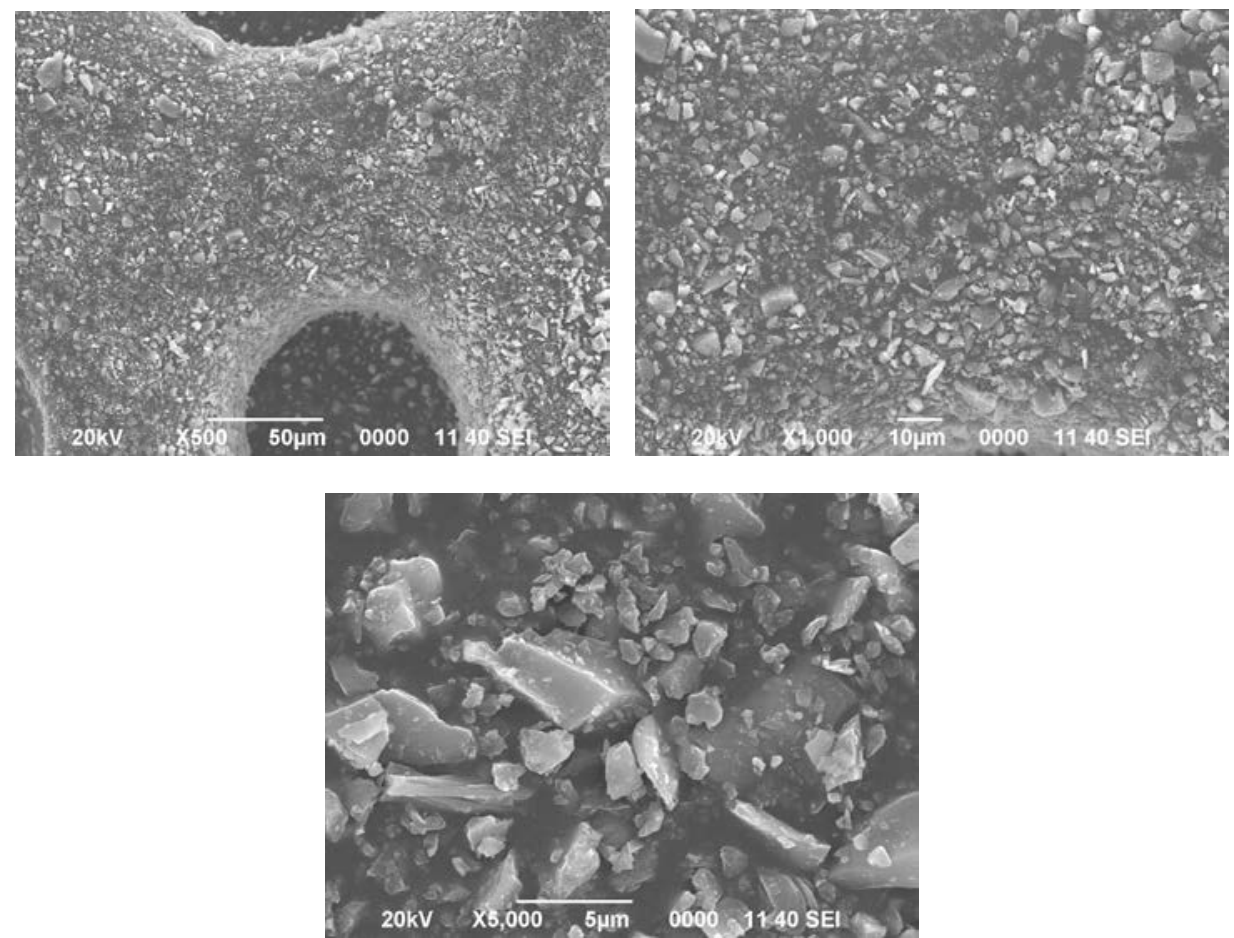

Gambar 9. Struktur mikro partikel Si sebelum pelindian. Perbesaran a). 500x, b). 1000x dan c). 5000x 

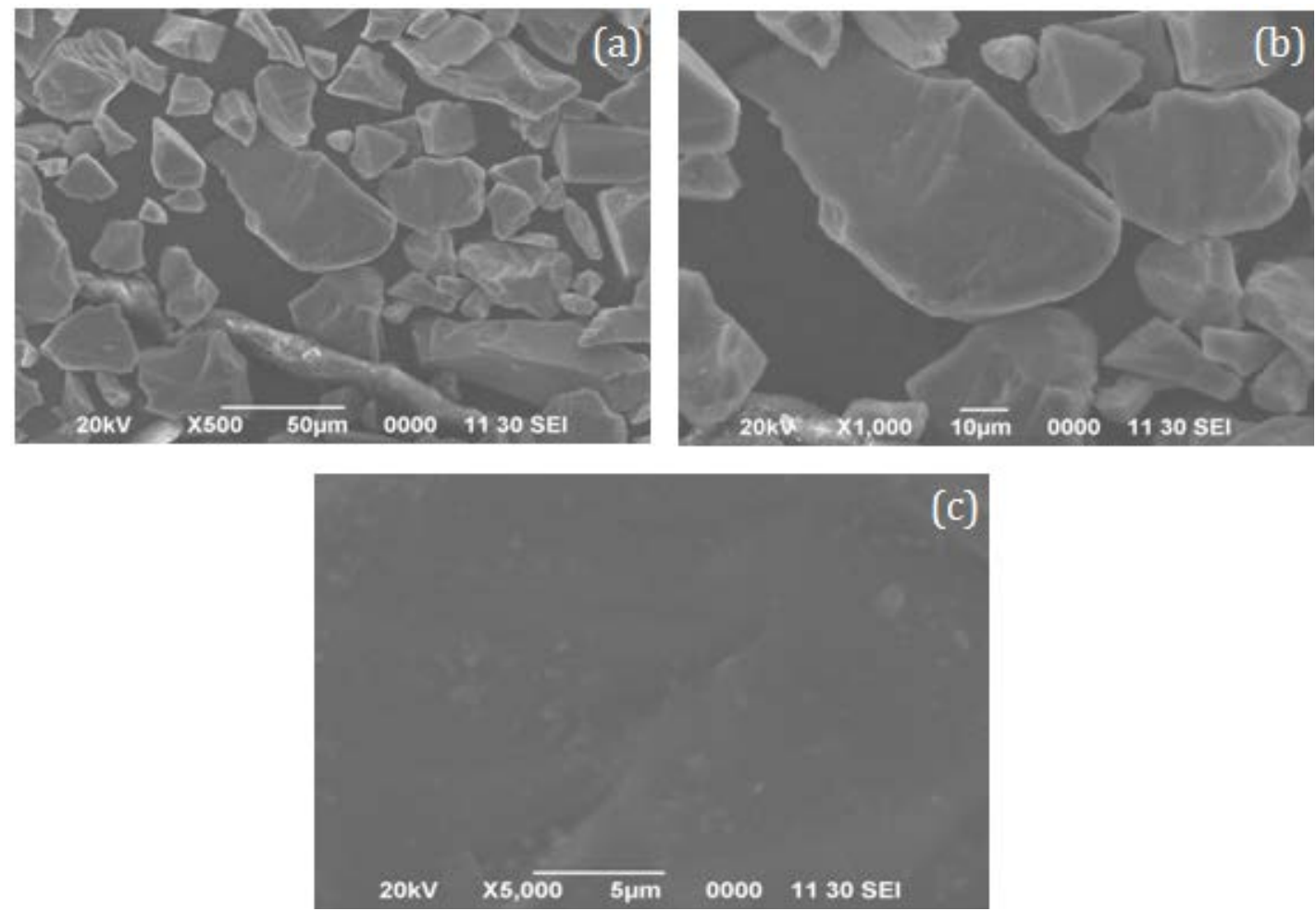

Gambar 10. Struktur mikro partikel Si hasil proses pelindian dengan waktu tahan 6 jam. Perbesaran a). 500x, b). 1000x dan c). 5000x
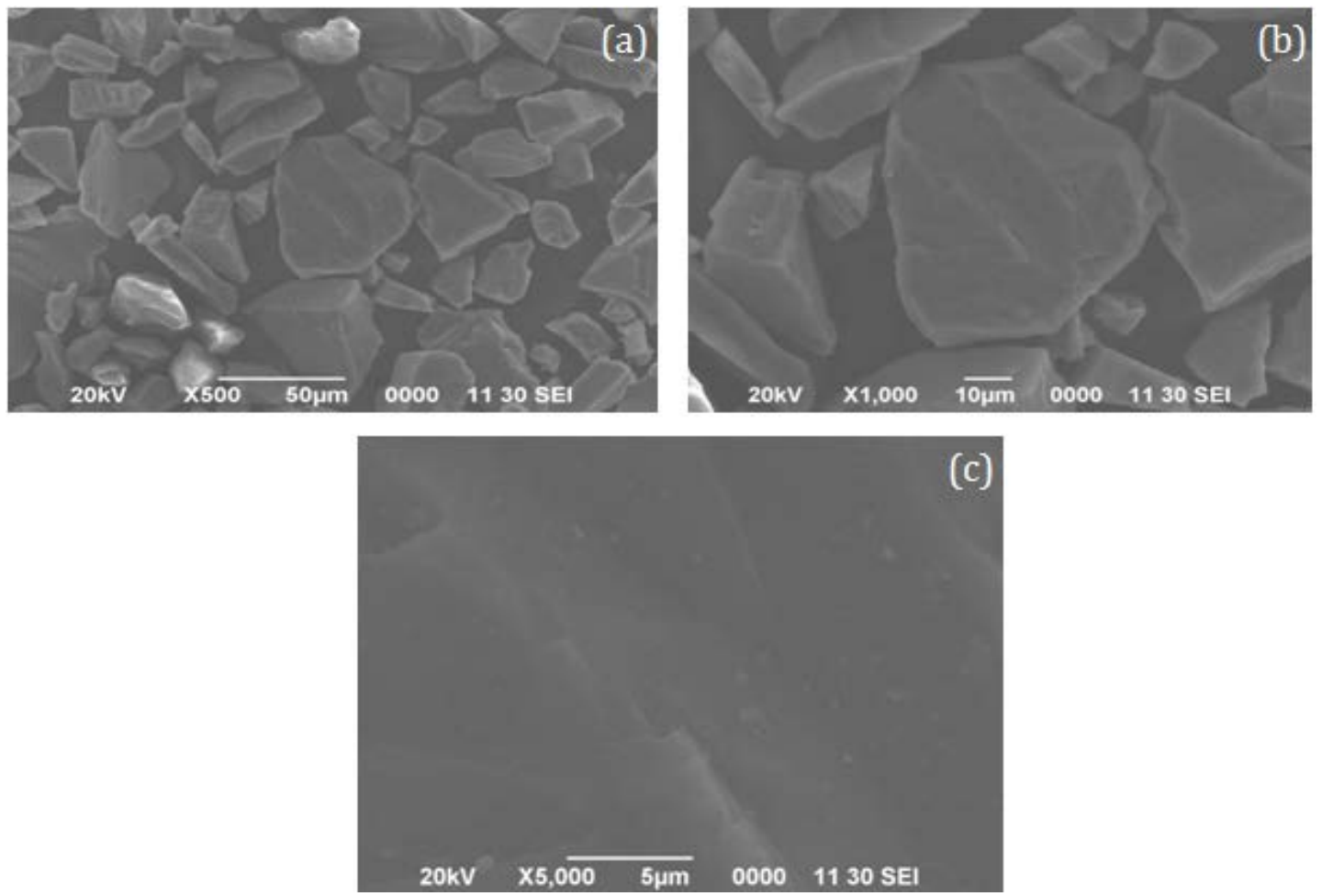

Gambar 11. Struktur mikro partikel Si hasil proses pelindian dengan waktu tahan 8 jam. Perbesaran a). 500x, b). 1000x dan c). 5000x 

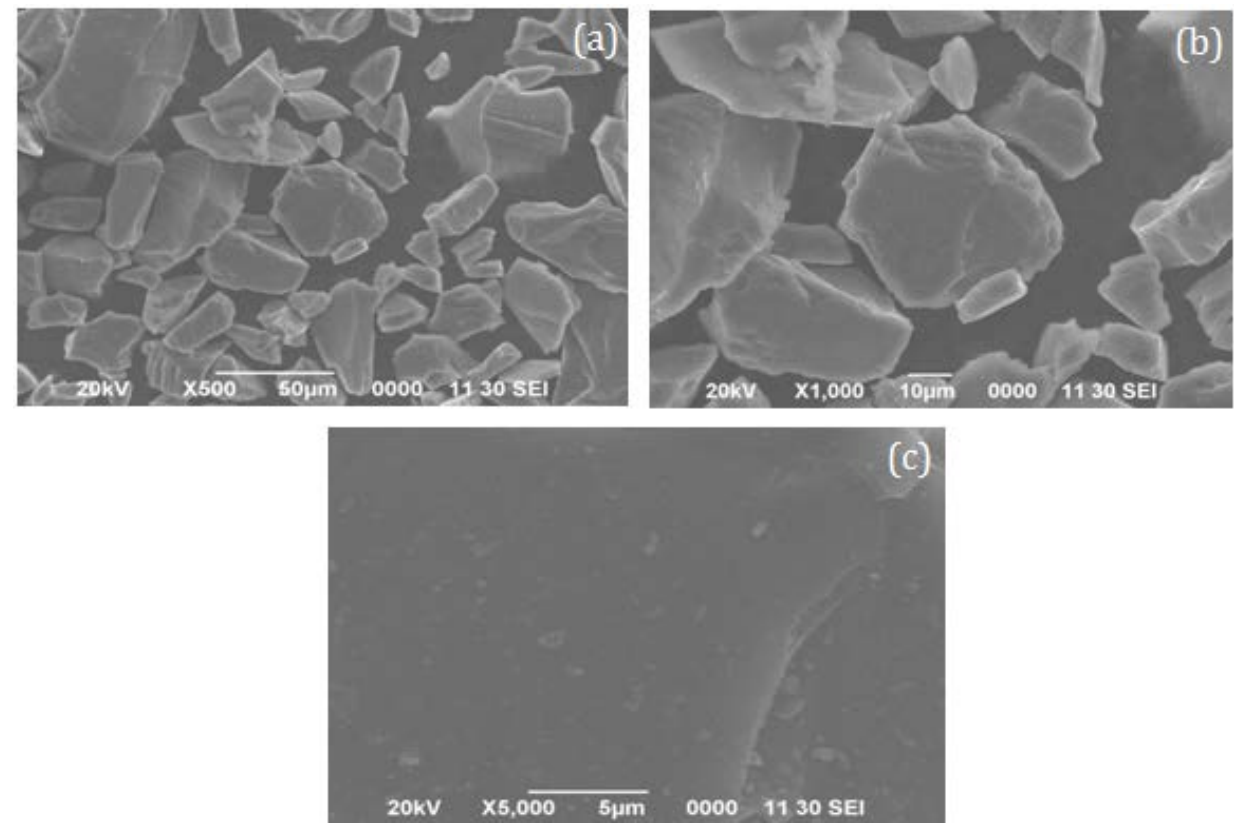

Gambar 12. Struktur mikro partikel Si hasil proses pelindian dengan waktu tahan 12 jam. Perbesaran a). 500x, b). 1000x dan c). 5000x

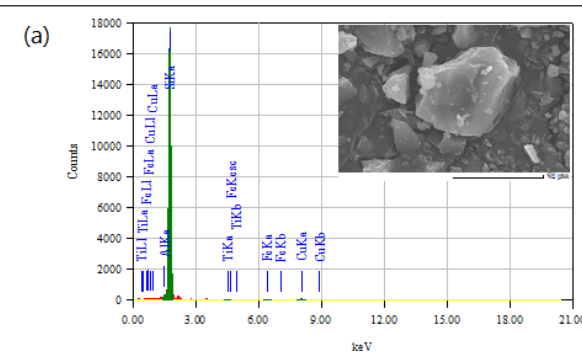

ZAF Method Standardless Quantitative Analysi Fitting Coefficient : 0.3861

Element (keV) Masso Erroro Atomo $\mathrm{K}$

$\begin{array}{llllll}\text { Al } K^{*} & 1.486 & 2.96 & 0.62 & 3.13 & 2.9158\end{array}$

$\begin{array}{llllll}\text { Si R } & 1.739 & 94.01 & 0.70 & 95.50 & 94.4454\end{array}$

$\begin{array}{llll}0.67 & 0.01 & 0.0101\end{array}$

$\begin{array}{lllll}6.398 & 0.19 & 2.81 & 0.10 & 0.1682\end{array}$

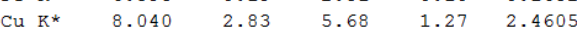
100.00



ZAF Method Standardless Quantitative

Analysis Fitting Coefficient : 0.2499

Element (keV) Mass\% Error\% Atom $\%$

$\begin{array}{lllllll}\text { Si K } & 1.739 & 100.00 & 0.50 & 100.00 & 100.0000\end{array}$

Total $\quad 100.00 \quad 100.00$



Gambar 13. Spektrum dan analisis semikuantitatif EDS percontoh hasil pelindian, a). Sebelum pelindian b). 6 jam, c). 8 jam, dan d). 12 jam 


\section{KESIMPULAN DAN SARAN}

Dari hasil percobaan pemurnian MG-Si dengan metode pelindian, didapatkan kesimpulan bahwa proses pelindian MG-Si dengan campuran larutan asam dengan konsentrasi $2,45 \mathrm{M} \mathrm{HCl}+1,2 \mathrm{M} \mathrm{HF}$ dapat mengurangi unsur pengotor yang terkandung di dalam MG-Si dan meningkatkan kemurnian seiring peningkatan waktu pelindian. Proses pelindian yang optimal pada percobaan ini didapatkan pada variasi waktu 12 jam yaitu mencapai efisiensi ekstraksi unsur pengotor Al dan Fe 99,99\% dan 99,92\%, sedangkan untuk unsur Ti mencapai 99,96\%. Adapun larutan pelindian selama 12 jam mempunyai efektivitas sebesar $99,97 \%$.

\section{UCAPAN TERIMA KASIH}

Penulis memberikan ucapan terima kasih kepada Pemerintah Indonesia yang memberikan bantuan dana penelitian pada Program Kompetensi Pusat Penelitian Metalurgi dan Material LIPI Tahun Anggaran 2015.

\section{DAFTAR PUSTAKA}

Cai, J., Luo, X., Lu, C., Hssrberg, G. M., Laurent, A., Kongstein, O. E. and Wang, S. (2012) "Purification of metallurgical grade silicon by electrorefining in molten salts," Transactions of Nonferrous Metals Society of China. The Nonferrous Metals Society of China, 22(12), pp. 3103-3107. doi: 10.1016/S10036326(11)61577-X.

Compaan, A. D. (2006) "Photovoltaics: Clean power for the 21st century," 90, pp. 21702180. doi: 10.1016/j.solmat.2006.02.017.

Hu, L., Wang, Z., Gong, X., Guo, Z. and Zhang, H. (2013) "Purification of metallurgical-grade silicon by $\mathrm{Sn}-\mathrm{Si}$ refining system with calcium addition," Separation and Purification Technology. Elsevier B.V., 118, pp. 699-703. doi: 10.1016/j.seppur.2013.08.013.

Jian, Z., Tingju, L., Xiaodong, M., Dawei, L. and Ning, L. (2009) "Optimization of the acid leaching process by using an ultrasonic field for metallurgical grade silicon*," 30(5), pp. 16. doi: 10.1088/1674-4926/30/5/053002.
Ma, X., Zhang, J., Wang, T. and Li, T. (2009) "Hydrometallurgical purification of metallurgical grade silicon," Rare Metals, 28(3), pp. 221-225. doi: 10.1007/s12598009-0043-1.

Martorano, M. A., Neto, J. B. F., Oliveira, T. S. and Tsubaki, T. O. (2011) "Refining of metallurgical silicon by directional solidification," Materials Science and Engineering: B. Elsevier B.V., 176(3), pp. 217-226. doi: 10.1016/j.mseb.2010.11.010.

Powerweb (2016) Wind Energy and Solar | Installed GW Capacity - Global and by Country, www.fi-powerweb.com. Available at: http://www.fi-powerweb.com/RenewableEnergy.html (Accessed: July 17, 2017).

Sarti, D. and Einhaus, R. (2002) "Silicon feedstock for the multi-crystalline photovoltaic industry," Solar Energy Materials and Solar Cells, 72(1-4), pp. 27-40. doi: 10.1016/S0927-0248(01)00147-7.

Silicor Materials (2015) The silicor process: Environmentally friendly solar silicon, www.silicormaterials.com. Available at: http://www.silicormaterials.com/component/d ocman/doc download/5-environmentalwhite-paper.html (Accessed: January 12, 2018).

Sun, Y.-H., Ye, Q.-H., Guo, C.-J., Chen, H.-Y., Lang, X., David, F., Luo, Q.-W. and Yang, C.M. (2013) "Purification of metallurgical-grade silicon via acid leaching, calcination and quenching before boron complexation," Hydrometallurgy. Elsevier B.V., 139, pp. 6472. doi: 10.1016/j.hydromet.2013.07.002.

Takiguchi, H. (2011) "Global flow analysis of crystalline silicon," in Basu, S. (ed.) Crystalline Silicon - Properties and Uses. InTech. doi: 10.5772/23573.

Tan, Y., Ren, S., Shi, S., Wen, S., Jiang, D., Dong, W., Ji, M. and Sun, S. (2014) "Removal of aluminum and calcium in multicrystalline silicon by vacuum induction melting and directional solidification," Vacuum. Elsevier Ltd, 99, pp. 272-276. doi: 10.1016/j.vacuum.2013.06.015.

Tavengwa, N. T., Cukrowska, E. and Chimuka, L. (2015) "Selective adsorption of uranium (VI) on $\mathrm{NaHCO} 3$ leached composite $\mathrm{Y}$ Methacryloxypropyltrimethoxysilane coated magnetic lon-imprinted polymers prepared by precipitation polymerization," South African Journal of Chemistry, 68, pp. 61-68. doi: 10.17159/0379-4350/2015/v68a10. 
Visnovec, K., Variawa, C., Utigard, T. and Mitrašinović, A. (2013) "Elimination of impurities from the surface of silicon using hydrochloric and nitric acid," Materials Science in Semiconductor Processing, 16(1), pp. 106-110. doi: 10.1016/j.mssp.2012.06.009.

Yoshikawa, T. and Morita, K. (2012) "An evolving method for solar-grade silicon production: Solvent refining," JOM, 64(8), pp. 946-951. doi: 10.1007/s11837-012-0371-8.
Zhang, L., Tan, Y., Li, J., Liu, Y. and Wang, D. (2013) "Study of boron removal from molten silicon by slag refining under atmosphere," Materials Science in Semiconductor Processing. Elsevier, 16(6), pp. 1645-1649. doi: 10.1016/j.mssp.2013.04.012.

Zhao, L., Wang, Z., Guo, Z. and Li, C. (2011) "Low-temperature purification process of metallurgical silicon," Transactions of Nonferrous Metals Society of China. The Nonferrous Metals Society of China, 21(5), pp. 1185-1192. doi: 10.1016/S10036326(11)60841-8. 
